\title{
PAMAQUINE NAPHTHOATE AS A PROPHYLACTIC FOR MALARIAL INFECTIONS ${ }^{1}$
}

\author{
BY HARRY A. FELDMAN, ${ }^{2}$ HENRY PACKER, ${ }^{3}$ FRANKLIN D. MURPHY,4 \\ AND ROBERT B. WATSON 5 \\ (From the Department of Preventive Medicine, University of Tennessee College of Medicine, \\ Memphis, and The Health and Safety Division of the Tennessee Valley Authority)
}

(Received for publication August 5, 1946)

Plasmoquine, 6-methoxy-8-(1-methyl-4-diethylamino) butyl-aminoquinoline, has been assigned the name "Pamaquine" by the United States Pharmacopea XII, and will be so referred to in this presentation. This anti-malarial has been so frequently discussed in the literature that a detailed review of its history will not be included here. Reference will be made only to those papers which bear directly upon the subject of this report.

In 1931, James et al $(1,2)$ conducted a series of experiments which showed that pamaquine in doses of $80 \mathrm{mgm}$. per day on a 1-1-6 regime (that is, administered on the day before, the day of, and for 6 days after inoculation with sporozoites) acted as a true causal prophylactic for both vivax and falciparum inoculations (Roumanian strain). This work is summarized in Table I. It will be noted that the number of subjects tested was small. In view of this fact, and because of the importance of the results obtained, it is surprising that despite the reputation for toxicity which the drug had acquired, it was not explored further until a decision was made by the Panel on Clinical Testing of Anti-malarials of the Committee on Medical Research to reevaluate this drug. This project was assigned the task of repeating and expanding the study of James during the summer of 1944. The information obtained to date forms the basis of this report.

\section{MATERIALS AND METHODS}

(a) Drug. Pamaquine naphthoate was the compound employed throughout this study. Approximately 45 per cent of this salt is considered to be active base. Consequently, dividing our doses by 2 yields a figure for comparison with doses generally referred to in the literature. The original lot of drug employed was supplied in the

1 Work done under contract with the Office of Scientific Research and Development.

2 Lieutenant Colonel, M.C., A.U.S.

${ }^{8}$ Associate Professor of Preventive Medicine.

Captain, M.C., A.U.S.

Principal Malariologist, T.V.A. form of 20-mgm. tablets. A second lot came as powder, and was capsulated locally. Both drug lots had such similar assays that they may be considered identical.

(b) Plasma concentrations. The plasma concentration of pamaquine was usually determined daily by means of a macrocolorimetric method (3) devised by Brodie et al. 6

(c) Subjects. Thirty-six white and colored males and females, who were relatively normal except for central nervous system syphilis, were employed in these experiments. Their ages ranged from 14 to 60 years. Each received complete physical, hematological, and blood chemistry examinations, urinalysis, $x$-rays of the chest, and electrocardiographic studies prior to the institution of treatment. Subsequently, these tests (except for the roentgenograms) were performed daily until experience indicated that with the exceptions of determinations of methemoglobin, plasma bilirubin, hematocrit indices, and leukocyte counts, such extensive tests were unnecessary, and they were discontinued as routine procedures.

(d) Methemoglobin. Methemoglobin formation is known to occur regularly during pamaquine administration. Since this may be a factor in the serious toxic reactions ascribed to the drug, it was considered necessary to determine its concentration daily. These determinations were performed by means of a simple procedure devised by Wendel (4). The test utilizes a photoelectric colorimeter, and requires only small amounts of blood.

(e) Parasitological methods. Inoculations were generally performed on the second day of treatment, although exceptions to this rule will be noted in the tabulated data. Laboratory-bred Anopheles quadrimaculatus, infected by feeding on patients with either $P$. vivax (McCoy) or $P$. falciparum (Costa) parasites, were allowed to inoculate by feeding. The mosquitoes were then killed, dissected, and the sporozoite content of their salivary glands estimated by a scale of pluses ranging from 1 (minimal) to 4 (maximal). Although in obvious excess, a goal of 16 pluses was sought for each infection. When necessary (and available) additional mosquitoes were fed on the same subject if the initial inoculum was less than 12 pluses. Ordinarily, $P$. vivax was reserved for whites and $P$. falciparum for negroes. However, it was sometimes necessary to use $P$. falciparum in whites, but no mishaps occurred.

- Dr. William B. Wendel, formerly of the Department of Biochemistry of the University of Tennessee College of Medicine, supervised all of our plasma level determinations. 
TABLE I*

Pamaquine as a true causal prophylactic (Summary of the experiments of Col. James)

\begin{tabular}{|c|c|c|c|c|c|c|c|c|}
\hline \multirow{3}{*}{ Group } & \multirow{3}{*}{$\begin{array}{l}\text { Number of } \\
\text { cases }\end{array}$} & \multirow{3}{*}{$\frac{\text { Doses** }}{\text { grams }}$} & \multicolumn{2}{|c|}{ Duration of administration } & \multicolumn{4}{|c|}{ Protection afforded (i.e., no evidence malaria) } \\
\hline & & & Total & $\begin{array}{l}\text { Days after day } \\
\text { of biting }\end{array}$ & \multicolumn{2}{|c|}{$\begin{array}{l}\text { Immediate } \\
\text { (up to } 30 \text { days) }\end{array}$} & \multicolumn{2}{|c|}{$\begin{array}{c}\text { Late } \\
\text { (followed up to } 3 \text { years) }\end{array}$} \\
\hline & & & days & & no. & per cent & no. & per cent \\
\hline
\end{tabular}

P. vivax

\begin{tabular}{|c|c|c|c|c|c|c|c|c|}
\hline $\begin{array}{c}\text { I } \\
\text { II } \\
\text { III } \\
\text { IV } \\
\text { V } \\
\text { VI } \\
\text { VII } \\
\text { (Rouman }\end{array}$ & $\begin{array}{c}\text { Not given } \\
10 \\
5 \\
2 \\
4 \\
5 \\
3 \\
\text { ian strain) }\end{array}$ & $\begin{array}{l}0.08 \\
(0.08 \text { first } \\
0.06 \\
0.04 \\
0.04 \\
0.04 \\
0.04 \\
0.08 \text { even } \\
0.08 \text { at ti } \\
\text { (no other }\end{array}$ & \begin{tabular}{|c|}
8 \\
3 days, 0.06 \\
7 \\
10 \\
7 \\
5 \\
4 \\
aing before inf \\
ime of infectio \\
r doses)
\end{tabular} & $\begin{array}{l}\text { last } 5 \text { days) } \\
5 \\
8 \\
5 \\
3 \\
2 \\
\text { |fection } \\
\text { ion }\end{array}$ & $\begin{array}{r}\text { All } \\
10 \\
5 \\
1 \\
2 \\
1 \\
2\end{array}$ & $\begin{array}{r}100 \\
100 \\
100 \\
50 \\
50 \\
20 \\
67\end{array}$ & $\begin{array}{c}\text { All } \\
5 \\
\text { No } \\
\text { No } \\
\text { No } \\
\text { No }\end{array}$ & 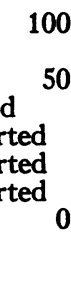 \\
\hline \multicolumn{9}{|c|}{ P. falciparum } \\
\hline $\begin{array}{l}\text { VIII } \\
\text { (Rouman }\end{array}$ & $\begin{array}{c}\text { Not given } \\
\mathbf{5} \\
\text { ian strain) }\end{array}$ & $\begin{array}{l}0.08 \\
(0.08 \text { first } \\
0.08\end{array}$ & $3 \underset{6}{8}$ & last $\begin{array}{c}6 \\
5 \\
\text { days) }\end{array}$ & $\begin{array}{r}\text { All } \\
5\end{array}$ & $\begin{array}{l}100 \\
100\end{array}$ & All & 100 \\
\hline
\end{tabular}

* From a summary prepared by Dr. Thomas C. Butler for the Board for the Coordination of Malarial Studies.

** Presumed to be base, and thus equivalent to about 45 per cent of the naphthoate.

Each patient had a pretreatment negative thick film examination for malaria parasites. Similar smears were examined daily from the seventh postinoculation day until discharge from the hospital. All negatives were followed for at least 30 days in the hospital, and at intervals thereafter, depending upon the location of the individual's home or place of custodial hospitalization. Prior to the employment of penicillin for the treatment of the patients' neuro-syphilis, 3 subjects received trophozoite inoculations after 31 to 34 days of negative observation. The malarial course of each of these was perfectly normal.

Although it had been shown that penicillin had no effect upon malaria trophozoites $(5,6)$, no information was available concerning its action on sporozoite or "exoerythrocytic" forms. Consequently, 2 patients were given, in divided doses, 240,000 units of penicillin on each of 10 days. On the second day, one patient was inoculated by mosquitoes with sporozoites of $P$. vivax (McCoy), and the other with $P$. falciparum (Costa). Both developed malarial infections within normal prepatent periods, and so it was felt that the subsequent expression of infections in our experimental subjects was not influenced by intensive penicillin therapy received during the early prepatent phase.

\section{RESULTS}

The results of the experiments will be presented in relation to each of the parasite species employed, and in order of increasing drug dosage. This is not the chronological order of experimentation, but probably represents a more rational approach for the reader.

(a) Experiments with P. vivax (McCoy). The trials with $P$. vivax ( $\mathrm{McCoy}$ ) are summarized in Table II. Two patients who received $160 \mathrm{mgm}$. of pamaquine naphthoate a day for the second to sixth postinoculation days had prepatent periods of 15 and 19 days. Although slightly longer than usual, these periods are not significantly different from those normally encountered. This experiment was designed to test the thesis that pamaquine acted against other than sporozoite and trophozoite forms. The results in these 2 patients do not indicate that such, at least, is the sole case.

In order to determine whether the activity of pamaquine depended upon a slowly excreted degradation product, $180 \mathrm{mgm}$. were administered daily for 8 days to 1 patient. Inoculation was accomplished on the ninth day, and 12 days later he developed a demonstrable parasitemia. In this instance, at least, the hypothesis appears to have been unfounded. 
Another patient, receiving $180 \mathrm{mgm}$. of pamaquine naphthoate a day, was inoculated on the second of the 2 days in which he received this dose. The appearance of an acute hemolytic anemia then necessitated drug withdrawal; parasitemia was evident on the eleventh postinoculation day.

One patient was given $160 \mathrm{mgm}$. of drug on the day before, the day of, and for 2 days following inoculation. The development of severe abdominal pain necessitated stoppage of the medication. He developed malaria on the eighteenth postinoculation day.

One patient was inoculated on the fourth of an 8-day course of $180 \mathrm{mgm}$. of pamaquine naphthoate daily. This was considered to represent a plasma mixture of "fresh" and "degraded" drug. Malaria was apparent on the twenty-third day, somewhat later than the normally expected date.

One subject received 80 , and another $120 \mathrm{mgm}$. of pamaquine naphthoate daily on the day before, the day of, and for 5 days following inoculation. The former developed malaria on the fourteenth, and the latter on the sixteenth day. In view of other similar experiments (vide infra) these dosages appear to have been indaequate.

Another patient was given $160 \mathrm{mgm}$. of pamaquine naphthoate daily on the same schedule as the 2 patients just described. After 34 negative days he received an intravenous inoculation of $P$. vivax (McCoy) trophozoites, and a normal malarial course ensued. Two hundred and thirty days later he was admitted for a malarial attack. Since blood-induced infections do not ordinarily relapse, this probably represents a break-through of the original sporozoite inoculation, but the slight factor of uncertainty eliminates this patient from further consideration.

Five patients were administered $160 \mathrm{mgm}$. of pamaquine naphthoate for each of 3 days, and then $120 \mathrm{mgm}$. daily for 5 days. Inoculation was per-

TABLE II

Summary of prophylaxis trials with pamaquine naphthoate vs. P. vivax (McCoy)

\begin{tabular}{|c|c|c|c|c|c|c|c|c|c|c|c|c|c|}
\hline $\begin{array}{c}\text { Drug } \\
\text { schedule }\end{array}$ & $\underset{\text { tient }}{\mathrm{Pa}-}$ & Race & Age & Wgt. & Dosage & $\begin{array}{c}\text { Num- } \\
\text { ber } \\
\text { days }\end{array}$ & $\left|\begin{array}{c}\text { Num- } \\
\text { ber } \\
\text { doses }\end{array}\right|$ & $\begin{array}{c}\text { Mg. } \\
\text { per } \\
\text { kg.* }\end{array}$ & $\begin{array}{l}\text { Total } \\
\text { dose }\end{array}$ & $\begin{array}{c}\text { Sporo- } \\
\text { zoite } \\
\text { doses** }\end{array}$ & $\begin{array}{c}\text { Pre- } \\
\text { patent } \\
\text { days }\end{array}$ & $\begin{array}{l}\text { Days } \\
\text { neg. } \\
\text { obs. }\end{array}$ & Remarks \\
\hline $0-0-0-5^{* * *}$ & $\begin{array}{l}\text { SHE } \\
\text { JOH }\end{array}$ & $\begin{array}{l}\mathbf{W} \\
\mathbf{W}\end{array}$ & $\begin{array}{c}\text { yrs. } \\
32 \\
40\end{array}$ & $\begin{array}{c}\mathrm{kgm} . \\
77 \\
66\end{array}$ & 40 mgm. q. 6 h. & $\begin{array}{l}5 \\
5\end{array}$ & $\begin{array}{l}20 \\
20\end{array}$ & $\begin{array}{l}2.1 \\
2.4\end{array}$ & $\begin{array}{l}\text { grams } \\
0.8 \\
0.8\end{array}$ & $\begin{array}{l}14 \\
15\end{array}$ & $\begin{array}{l}15 \\
19\end{array}$ & . & $\left\{\begin{array}{l}\text { Drug during 2nd-6th } \\
\text { post-inoc. days }\end{array}\right.$ \\
\hline $8-0-0$ & BYR & $\mathbf{W}$ & 50 & 65 & 22.5 mgm. q. $3 \mathrm{~h}$. & 8 & 64 & 2.8 & 1.44 & 12 & 12 & & \\
\hline $1-1-0$ & JOR & C & 38 & 55 & 22.5 mgm. q. 3 h. & 2 & 16 & 3.3 & 0.36 & 19 & 11 & & Hemolytic anemia \\
\hline $1-1-2$ & STA & W & 26 & 58 & 40 mgm. q. 6 h. & 4 & 16 & 2.8 & 0.64 & 20 & 18 & & Severe abd. pain \\
\hline $3-1-4$ & FER & $\mathbf{W}$ & 24 & 74 & 22.5 mgm. q. 3 h. & 8 & 64 & 2.4 & 1.44 & 16 & 23 & & \\
\hline $1-1-5$ & $\begin{array}{l}\text { STE } \\
\text { BAK } \\
\text { PHI }\end{array}$ & $\begin{array}{l}\mathbf{W} \\
\mathbf{W} \\
\mathbf{W}\end{array}$ & $\begin{array}{l}40 \\
25 \\
39\end{array}$ & $\begin{array}{l}83 \\
64 \\
65\end{array}$ & $\begin{array}{l}20 \text { mgm. q. } 6 \mathrm{~h} . \\
20 \mathrm{mgm} . \mathrm{q} .4 \mathrm{~h} . \\
40 \mathrm{mgm} . \mathrm{q} .6 \mathrm{~h} .\end{array}$ & $\begin{array}{l}7 \\
7 \\
7\end{array}$ & $\begin{array}{l}28 \\
42 \\
28\end{array}$ & $\begin{array}{l}1.0 \\
1.9 \\
2.5\end{array}$ & $\begin{array}{l}0.56 \\
0.84 \\
1.12\end{array}$ & $\begin{array}{l}20 \\
20 \\
16\end{array}$ & $\begin{array}{l}14 \\
16\end{array}$ & 34 & Troph. inoc. 35th day \\
\hline $1-1-6$ & $\begin{array}{l}\text { MOO } \\
\text { WIL }\end{array}$ & $\begin{array}{l}\mathbf{W} \\
\mathbf{W}\end{array}$ & $\begin{array}{l}24 \\
49\end{array}$ & $\begin{array}{l}80 \\
71\end{array}$ & $\left\{\begin{array}{l}40 \text { mgm. q. } 6 \text { h., } \\
\times 12,20 \text { mgm., } \\
q .4 \text { h. } \times 28\end{array}\right.$ & $\begin{array}{l}8 \\
8\end{array}$ & $\begin{array}{l}40 \\
40\end{array}$ & $\begin{array}{l}2.0 \\
2.3\end{array}$ & $\begin{array}{l}1.04 \\
1.04\end{array}$ & $\begin{array}{l}17 \\
16\end{array}$ & $\begin{array}{l}248 \\
194\end{array}$ & & \\
\hline & $\begin{array}{l}\text { POR } \\
\text { LEW } \\
\text { HAL }\end{array}$ & $\begin{array}{l}\mathbf{W} \\
\mathbf{W} \\
\mathbf{W}\end{array}$ & $\begin{array}{l}35 \\
50 \\
34\end{array}$ & $\begin{array}{l}60 \\
74 \\
69\end{array}$ & $\left\{\begin{array}{l}40 \text { mgm. q. } 6 \text { h. } \\
\times 12,20 \text { mgm. } \\
\text { q. } 4 \text { h. } \times 30\end{array}\right.$ & $\begin{array}{l}8 \\
8 \\
8\end{array}$ & $\begin{array}{l}42 \\
42 \\
42\end{array}$ & $\begin{array}{l}2.7 \\
2.2 \\
2.3\end{array}$ & $\begin{array}{l}1.08 \\
1.08 \\
1.08\end{array}$ & $\begin{array}{l}18 \\
16 \\
20\end{array}$ & & $\begin{array}{l}445 \\
443 \\
413\end{array}$ & \\
\hline & $\begin{array}{l}\text { BAS } \\
\text { JER } \\
\text { McC } \\
\text { SIM } \\
\text { BEA }\end{array}$ & $\begin{array}{l}\mathbf{W} \\
\mathbf{W} \\
\mathbf{W} \\
\mathbf{W} \\
\mathbf{W}\end{array}$ & $\begin{array}{l}27 \\
44 \\
14 \\
41 \\
29\end{array}$ & $\begin{array}{l}69 \\
50 \\
60 \\
74 \\
65\end{array}$ & 22.5 mgm. q. 3 h. & $\begin{array}{l}8 \\
8 \\
8 \\
8 \\
8\end{array}$ & $\begin{array}{l}64 \\
64 \\
64 \\
64 \\
64\end{array}$ & $\begin{array}{l}2.6 \\
3.6 \\
3.0 \\
2.4 \\
2.8\end{array}$ & $\begin{array}{l}1.44 \\
1.44 \\
1.44 \\
1.44 \\
1.44\end{array}$ & $\begin{array}{l}17 \\
18 \\
17 \\
19 \\
18\end{array}$ & $\begin{array}{r}22 \\
262 \\
209\end{array}$ & $\begin{array}{l}121 \\
187\end{array}$ & \\
\hline
\end{tabular}

* Where combinations of doses were employed, this figure was based upon the amount of drug administered during the first day.

** Sporozoite content of salivary glands of infecting mosquitoes estimated by scale of pluses ranging from one (minimal) to four (maximal). This column represents total for the individual patient.

*** The first number refers to the preinoculation period, the second, to the day of inoculation, and those that follow to the postinoculation period. 
formed on the second day. None of this group suffered an immediate primary attack. One had a delayed primary episode at 194 days, another at 248 days, while the remaining 3 have now been followed for 413,443 , and 445 days respectively, without demonstrable evidence of malaria. Since no untreated patient on this service has ever failed to develop malaria within less than 20 days after mosquito inoculation, these results are of considerable significance.

Five patients received $180 \mathrm{mgm}$. of pamaquine naphthoate daily for 8 days with inoculation on the second day. One of these developed clinical malaria on the twenty-second day, another at 209 days, and the third at 262 days. The other 2 have not developed demonstrable infections during 121 and 187 observation days, respectively.

In view of the small numbers of subjects dealt with, no attempt will be made to explain the differences in the results obtained in the last 2 groups.

Four random-selected, untreated patients who received similar $P$. vivax ( $\mathrm{McCoy}$ ) inoculations at various times during this study had prepatent periods of 11 to 16 days. (b) Experiments with P. falciparum (Costa). The experiments with this species are summarized in Table III.

One patient received $160 \mathrm{mgm}$. of pamaquine naphthoate on the day of inoculation only, and developed malaria 11 days later. The mosquitoes were fed midway during the drug course. In another instance, inoculation occurred after the administration of $157.5 \mathrm{mgm}$. of pamaquine naphthoate, when the drug had to be stopped because of what was interpreted as a severe lumbar puncture reaction. Malaria was evident 9 days later.

Of 2 patients who received $160 \mathrm{mgm}$. of drug a day for 3 days (inoculation on the second day), one had a prepatent period of 14 days, whereas the other has been negative for 489 days. The latter received the smallest sporozoite dose $\left(8^{+}\right)$of any patient in our series, but such inocula ordinarily are sufficient to produce infection.

One subject, whose drug had to be withdrawn after 4 days on the $160 \mathrm{mgm}$. schedule because of an acute hemolytic anemia, developed malaria on the thirteenth day. Inoculation, as usual, was done on the second day.

TABLE III*

Summary of prophylaxis trials with pamaquine naphthoate vs. P. falciparum (Costa)

\begin{tabular}{|c|c|c|c|c|c|c|c|c|c|c|c|c|c|}
\hline $\begin{array}{l}\text { Drug } \\
\text { eched- } \\
\text { ule }\end{array}$ & $\underset{\text { tient }}{\mathrm{Pa}-}$ & Race & Age & Wgt. & Dosage & $\begin{array}{l}\text { Num- } \\
\text { ber } \\
\text { days }\end{array}$ & $\begin{array}{c}\text { Num- } \\
\text { ber } \\
\text { doses }\end{array} \mid$ & $\begin{array}{c}\text { Mgm. } \\
\text { per } \\
\text { kgm. }\end{array}$ & $\begin{array}{l}\text { Total } \\
\text { dose }\end{array}$ & $\begin{array}{c}\text { Sporo- } \\
\text { zoite } \\
\text { dose }\end{array}$ & $\begin{array}{c}\text { Pre- } \\
\text { patent } \\
\text { days }\end{array}$ & $\begin{array}{l}\text { Days } \\
\text { neg. } \\
\text { obs. }\end{array}$ & Remarks \\
\hline $0-1-0$ & BAK & W & $\begin{array}{l}y r s . \\
25\end{array}$ & kgm. & 40 mgm. q. 6 h. & 1 & 4 & 2.4 & $\begin{array}{l}\text { grams } \\
0.16\end{array}$ & 26 & 11 & & \\
\hline $1-0-0$ & CIT & W & 33 & 59 & 22.5 mgm. q. $3 \mathrm{~h}$. & 1 & 7 & 3.1 & 0.157 & 15 & 9 & & Drug stopped. LP Re- \\
\hline $1-1-1$ & $\begin{array}{l}\text { COO } \\
\text { SLA }\end{array}$ & $\begin{array}{l}\mathbf{C} \\
\mathbf{W}\end{array}$ & $\begin{array}{l}19 \\
52\end{array}$ & $\begin{array}{l}57 \\
60\end{array}$ & 40 mgm. q. $6 \mathrm{~h}$. & $\begin{array}{l}3 \\
3\end{array}$ & $\begin{array}{l}12 \\
12\end{array}$ & $\begin{array}{l}2.8 \\
2.7\end{array}$ & $\begin{array}{l}0.48 \\
0.48\end{array}$ & $\begin{array}{r}8 \\
27\end{array}$ & 14 & 489 & \\
\hline $1-1-2$ & BRO & C & 41 & 51 & 40 mgm. q. 6 h. & 4 & 15 & 3.0 & 0.6 & 21 & 13 & & Hemolytic anemia \\
\hline $1-1-3$ & SMI & W & 42 & 60 & 22.5 mgm. q. 3 h. & 5 & 40 & 3.0 & 0.9 & 20 & & 226 & \\
\hline 4-1-3 & MOR & C & 48 & 60 & 22.5 mgm. q. 3 h. & 8 & 64 & 3.0 & 1.44 & 11 & & 254 & \\
\hline $1-1-4$ & $\begin{array}{l}\text { JAC } \\
\text { HOL }\end{array}$ & $\stackrel{\mathbf{C}}{\mathbf{C}}$ & $\begin{array}{l}49 \\
44\end{array}$ & $\begin{array}{l}63 \\
53\end{array}$ & 22.5 mgm. q. 3 h. & $\begin{array}{l}6 \\
6\end{array}$ & $\begin{array}{l}48 \\
48\end{array}$ & $\begin{array}{l}2.9 \\
3.4\end{array}$ & $\begin{array}{l}1.08 \\
1.08\end{array}$ & $\begin{array}{l}24 \\
17\end{array}$ & & $\begin{array}{l}232 \\
158^{* *}\end{array}$ & \\
\hline $1-1-5$ & $\begin{array}{l}\text { LEF } \\
\text { JON } \\
\text { BUT }\end{array}$ & $\begin{array}{l}\text { C } \\
\text { C } \\
\text { C }\end{array}$ & $\begin{array}{l}33 \\
36 \\
14\end{array}$ & $\begin{array}{l}48 \\
42 \\
53\end{array}$ & 40 mgm. q. 6 h. & $\begin{array}{l}7 \\
7 \\
7\end{array}$ & $\begin{array}{l}28 \\
28 \\
28\end{array}$ & $\begin{array}{l}3.3 \\
3.8 \\
3.0\end{array}$ & $\begin{array}{l}1.12 \\
1.12 \\
1.12\end{array}$ & $\begin{array}{l}14 \\
14 \\
16\end{array}$ & & $\begin{array}{r}31 \\
31 \\
483\end{array}$ & $\begin{array}{l}\text { Troph. inoc. 32nd day } \\
\text { Troph. inoc. 32nd day }\end{array}$ \\
\hline $1-1-6$ & $\begin{array}{l}\text { WEL } \\
\text { RIN }\end{array}$ & $\begin{array}{l}\mathbf{C} \\
\mathbf{W}\end{array}$ & $\begin{array}{l}31 \\
40\end{array}$ & $\begin{array}{l}60 \\
72\end{array}$ & $\left\{\begin{array}{l}40 \text { mgm. q. } 6 \text { h. } \times 12, \\
20 \text { mgm. q. } 4 \text { h. } \times 30\end{array}\right.$ & $\begin{array}{l}8 \\
8\end{array}$ & $\begin{array}{l}40 \\
42\end{array}$ & $\begin{array}{l}2.7 \\
2.2\end{array}$ & $\begin{array}{l}1.04 \\
1.08\end{array}$ & $\begin{array}{l}13 \\
21\end{array}$ & & $\begin{array}{l}455 \\
349\end{array}$ & $\because$ \\
\hline & $\begin{array}{l}\text { DAV } \\
\text { PRO } \\
\text { ScH }\end{array}$ & $\begin{array}{l}\mathbf{C} \\
\mathbf{W} \\
\mathbf{W}\end{array}$ & $\begin{array}{l}30 \\
34 \\
45\end{array}$ & $\begin{array}{l}61 \\
69 \\
54\end{array}$ & 22.5 mgm. q. 3 h. & $\begin{array}{l}8 \\
8 \\
8\end{array}$ & $\begin{array}{l}64 \\
64 \\
64\end{array}$ & $\begin{array}{l}3.0 \\
2.6 \\
3.3\end{array}$ & $\begin{array}{l}1.44 \\
1.44 \\
1.44\end{array}$ & $\begin{array}{l}20 \\
20 \\
20\end{array}$ & & $\begin{array}{l}245 \\
181 \\
221\end{array}$ & \\
\hline
\end{tabular}

* Table II footnotes apply to Table III.

** Died subsequently of non-malarial condition. 
PAMAQUINE NAPHTHOATE FOR MALARIA PROPHYLAXIS

TABLE IV

Plasma concentrations of pamaquine expressed as gammas per liter

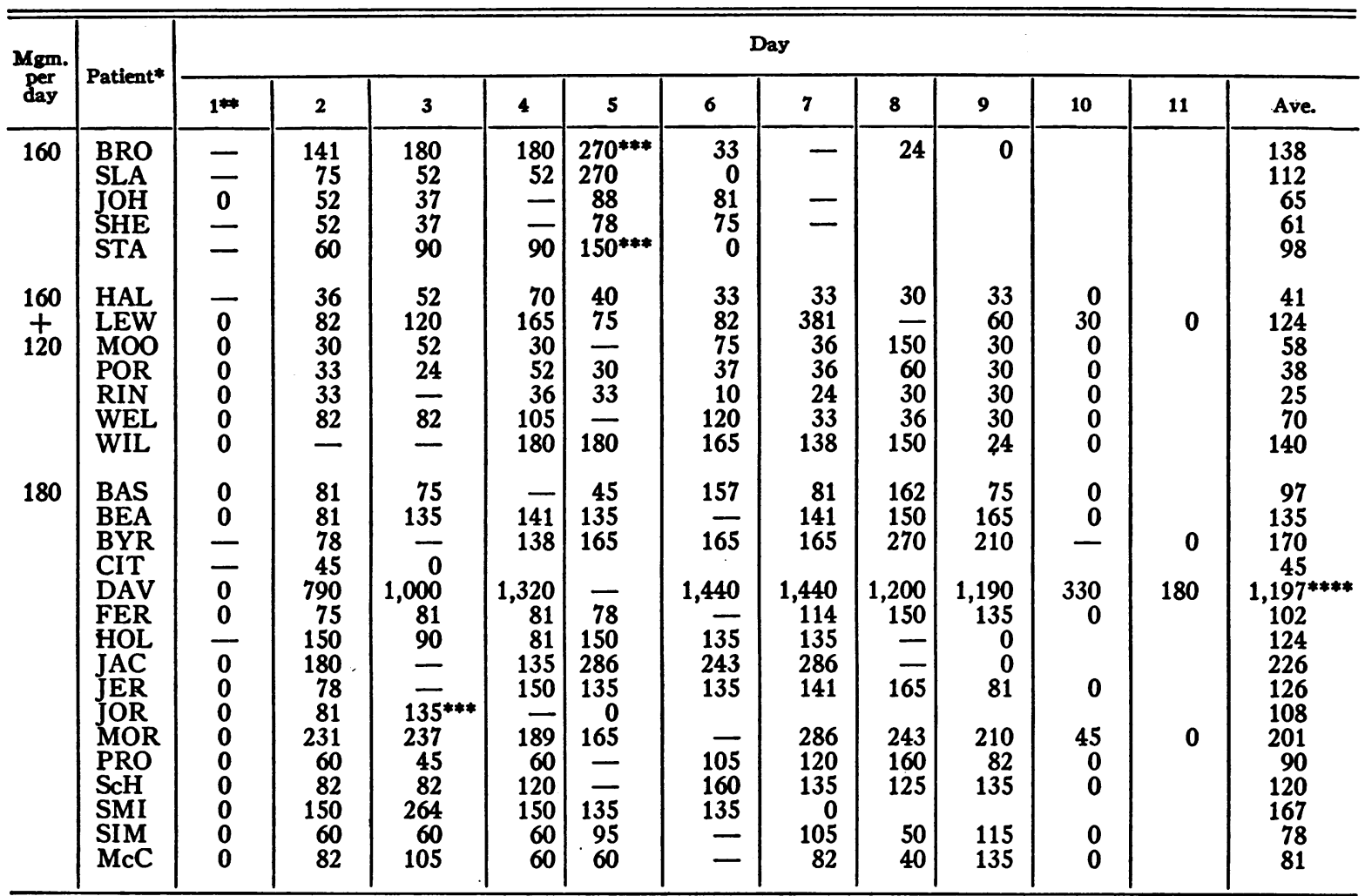

* Identification corresponds to Tables II and III.

** The day drug administration was begun but prior to the first dose. - not done, 0 no drug detectable in plasma. *** Drug stopped.

**** Determination of plasma concentration not done on 12th day and not detectable on 13th day.

In the next group, both patients received drug for 3 days following the day of inoculation, but whereas one had been treated for 3 days prior to that date, the other received the drug for only 1 day before inoculation. The dose was $180 \mathrm{mgm}$. a day. Neither has developed malaria during 254 and 184 days of observation.

Two others who received $180 \mathrm{mgm}$. of pamaquine naphthoate on the day before, the day of, and for 4 days following inoculation, have been free of disease for $158^{7}$ and 189 days, respectively.

Of 3 patients who received $160 \mathrm{mgm}$. of drug for 7 days (inoculated on the second day), 2 were given trophozoites intravenously after 31 days of negative observation, and so have been dropped from the study, while the third has been free of malaria for 483 days.

Two subjects have had no demonstrable malaria

7 Died subsequently of non-malarial condition. for 349 and 455 days following a drug schedule of $160 \mathrm{mgm}$. a day for 3 days, followed by $120 \mathrm{mgm}$. for each of 5 days. Inoculation was accomplished on the second day.

Three patients who were on the 8-day, 180 mgm. daily schedule have not developed malaria during 245, 181 and 221 days, respectively.

A representative group of 6 untreated patients who received $P$. falciparum (Costa) sporozoites by the same inoculation method while these studies were in progress had prepatent periods of 8 to 12 days.

(c) Plasma pamaquine levels. The plasma concentrations of pamaquine determined in 28 patients are summarized in Table IV. These demonstrate quite clearly that measurable pamaquine is both rapidly absorbed into, and excreted from, the plasma. However, it is just as apparent that the plasma level attained (as measured by 
TABLE V

Methemoglobinemia as per cent of total hemoglobin in patients receiving pamaquine naphthoate

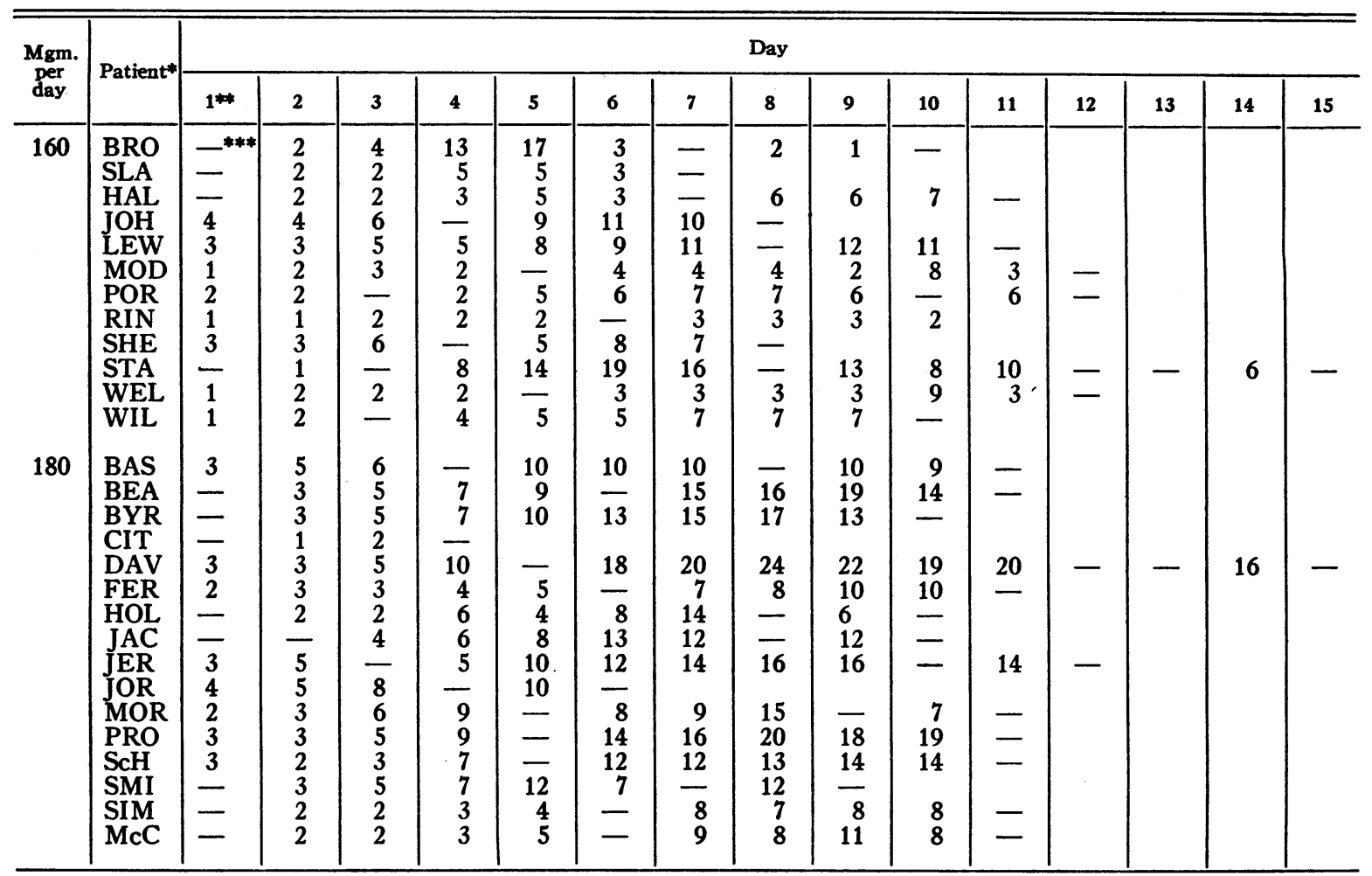

* Identification corresponds to Tables II and III.

** The day drug administration was begun, but prior to the first dose.

*** Not done.

the method employed) bears little relationship to the mgm. per $\mathrm{kgm}$. dose, the various toxic reactions produced, or to the degree of protection attained. In general, plasma concentrations were greater in those whose total drug intake was greater. This is illustrated by the averages for the dosage groups.

(d) Toxic reactions. Although methemoglobinemia was regularly encountered at all dosage levels (Table V), more tended to be formed as the pamaquine intake was increased. Such formation occurred quite soon after the initiation of therapy, and persisted for some days after the drug was withdrawn. No methylene blue could be employed for the treatment of this state because of its effect upon malarial parasites. Of itself, the methemoglobinemia did not appear to cause any difficulty, although high levels were attained in individuals who suffered other severe toxic reactions.

Two instances of acute hemolytic anemia were encountered. Both occurred in negro patients, and both had their onset soon after therapy was begun. In neither instance was there any history of preceding malaria or exposure to pamaquine. Prompt withdrawal of the drug and intensive erythrocyte transfusions produced complete recoveries. The data concerned with these 2 patients are summarized in Tables VI and VII. In addition, Table VII includes a summary of attempts to reproduce this hemolysis in vitro. All of the latter were failures.

An opportunity to restudy patient BRO presented itself some 3 months after the initial hemolytic episode. At this date he was fully recovered and normal in all respects. He was placed on a drug schedule which called for $160 \mathrm{mgm}$. of pamaquine naphthoate a day for 3 days, followed by $120 \mathrm{mgm}$. for each of 5 following days, but the drug had to be withdrawn on the fifth day because of another hemolytic reaction (Table VIII). This indicates that the susceptibility to acute he- 
TABLE VI

Hemolytic reaction to pamaquine naphthoate

Patient: JOR. Negro, male. P. vivax (McCoy)

\begin{tabular}{|c|c|c|c|c|c|c|c|c|c|}
\hline Date & Hour & Drug & $\begin{array}{c}\text { Plasma } \\
\text { level }\end{array}$ & $\underset{\text { crit }}{\text { Hemato- }}$ & $\underset{\text { bilirubin }}{\text { Plasma }}$ & $\begin{array}{c}\text { Total } \\
\text { hb. }\end{array}$ & $\begin{array}{l}\text { Per cent } \\
\text { met-hb. }\end{array}$ & $\begin{array}{c}\text { Toxic } \\
\text { manifestations }\end{array}$ & Remarks \\
\hline $7-19$ & 8:30 a.m. & *** & $\begin{array}{c}\gamma \text { per } l . \\
0\end{array}$ & 一 & $\begin{array}{c}\text { mgm. } \\
\text { per cent } \\
\text {-* }\end{array}$ & $\begin{array}{l}\text { grams } \\
\text { per cent } \\
14\end{array}$ & 4 & & \\
\hline $\begin{array}{l}7-20 \\
7-21 \\
7-22\end{array}$ & $\begin{array}{l}\text { 8:30 a.m. } \\
\text { 8:30 a.m. } \\
\text { 8:30 a.m. }\end{array}$ & Stopped & $\begin{array}{r}81 \\
135 \\
-\end{array}$ & $\begin{array}{l}38 \\
37.5 \\
28.5\end{array}$ & $\begin{array}{l}1.21 \\
3.65 \\
3.71\end{array}$ & $\begin{array}{l}12.8 \\
11.1 \\
-\end{array}$ & $\begin{array}{l}5 \\
8 \\
\end{array}$ & $\begin{array}{l}\text { Weakness } \\
\text { Headache, }\end{array}$ & $19+$ Sporozoites \\
\hline $7-23$ & 8:30 a.m. & & $\mathbf{0}$ & 21 & 2.61 & 9.6 & 7 & $\begin{array}{l}\text { Dizziness, } \\
\text { nausea, and }\end{array}$ & \\
\hline & $\begin{array}{l}\text { 2:30 p.m. } \\
\text { 7:30 p.m. }\end{array}$ & & 一 & 28 & 2.2 & - & - & onstos & $\begin{array}{l}1 \text { hour after } 400 \\
\text { ml. RBC IV } \\
600 \mathrm{ml} \text {. RBC IV }\end{array}$ \\
\hline $\begin{array}{l}7-24 \\
7-25 \\
7-27\end{array}$ & $\begin{array}{l}\text { 8:30 a.m. } \\
\text { 8:30 a.m. } \\
\text { 8:30 a.m. }\end{array}$ & & - & $\begin{array}{l}32.5 \\
34 \\
32.5\end{array}$ & $\begin{array}{l}3.6 \\
1.21 \\
0.23\end{array}$ & E & E & None & \\
\hline
\end{tabular}

* Not done.

** Mgm. 22.5 q. 3 h. $\times 16$.

molytic reactions because of pamaquine intake persists for 3 months at least.

Since the question of the role of various blood grouping factors in the production of this type of hemolytic reaction might be raised, serum samples obtained from patients BRO and JOR (as well as from several other individuals who had received similar amounts of the same drug with-

TABLE VII

Hemolytic reaction to pamaquine naphthoate (first course)

Patient: BRO. Negro, male. $P$. falciparum (Costa)

\begin{tabular}{|c|c|c|c|c|c|c|c|c|c|}
\hline Date & Hour & Drug & $\begin{array}{c}\text { Plasma } \\
\text { level }\end{array}$ & $\begin{array}{c}\text { Hemato- } \\
\text { crit }\end{array}$ & $\underset{\text { bilirubin }}{\text { Plasma }}$ & $\begin{array}{l}\text { Total } \\
\text { hb. }\end{array}$ & $\begin{array}{l}\text { Per cent } \\
\text { met-hb. }\end{array}$ & Toxic manifestations & Remarks \\
\hline & & & $\gamma$ per $l$. & & $\begin{array}{l}\text { mgm. } \\
\text { per cent }\end{array}$ & $\begin{array}{l}\text { grams } \\
\text { per cent }\end{array}$ & & & \\
\hline & $\begin{array}{l}\text { 8:30 a.m. } \\
\text { 12:00 p.m. }\end{array}$ & $\stackrel{* *}{\text { Started }}$ & 0 & - & - & & - & & ' \\
\hline $\begin{array}{l}2-13 \\
2-14\end{array}$ & $\begin{array}{l}\text { 8:30 a.m. } \\
\text { 8:30 a.m. }\end{array}$ & & $\begin{array}{l}141 \\
180\end{array}$ & $\begin{array}{l}45 \\
43\end{array}$ & - & $\begin{array}{l}14.4 \\
14.2\end{array}$ & $\begin{array}{l}2 \\
4\end{array}$ & & $\begin{array}{l}21 \text { + sporozoites } \\
\text { Plasma slightly } \\
\text { discolored }\end{array}$ \\
\hline $2-15$ & $\begin{array}{c}\text { 8:30 a.m. } \\
* * *\end{array}$ & & 180 & 38 & 2.4 & 13.1 & 13 & $\begin{array}{l}\text { Slight abdominal } \\
\text { pain }\end{array}$ & \\
\hline $2-16$ & & & 270 & 31 & 3.4 & 10.1 & 17 & $\begin{array}{l}\text { Slight abdominal } \\
\text { pain }\end{array}$ & \\
\hline $2-17$ & $\begin{array}{l}\text { 2:00 p.m. } \\
\text { 8:30 a.m. }\end{array}$ & Stopped & 33 & 25 & 3.0 & 7.7 & 3 & Abd. pain, weak- & Total, $0.58 \mathrm{gm}$ \\
\hline & 2:30 p.m. & & - & 33 & 4.9 & 9.6 & 一 & $\begin{array}{l}\text { Abd. pain, weak- } \\
\text { ness, pallor }\end{array}$ & $\begin{array}{l}1 \text { hour after } 400 \\
\text { ml. RBC IV }\end{array}$ \\
\hline $2-18$ & 10:30 a.m. & & 一 & 30 & 3.9 & 7.8 & 一 & $\begin{array}{l}\text { Abd. pain, weak- } \\
\text { ness, pallor }\end{array}$ & Followed by 600 \\
\hline $\begin{array}{l}2-19 \\
2-20 \\
2-23\end{array}$ & $\begin{array}{l}\text { 8:30 a.m. } \\
\text { 8:30 a.m. } \\
\text { 8:30 a.m. }\end{array}$ & & $\begin{array}{r}24 \\
0\end{array}$ & $\begin{array}{l}37 \\
34 \\
38\end{array}$ & $\begin{array}{l}2.2 \\
0.6 \\
-\end{array}$ & $\begin{array}{l}10.8 \\
10.7\end{array}$ & $\begin{array}{r}2 \\
1 \\
-\end{array}$ & $\begin{array}{l}\text { Slight abd. pain } \\
\text { None }\end{array}$ & Clinical recovery \\
\hline
\end{tabular}

* Not done.

** 40 Mgm. q. 6 hrs. $\times 12$, then 20 mgm. q. 4 hrs. $\times 5$.

*** (a) Erythrocyte fragility-normal limits. (b) BRO's washed ( $3 \times$ in PSS) RBC suspended in homologous plasma and in plasma of control of same blood group (who had had similar pamaquine course 2 weeks previously without mishap) in concentration of hematocrit for this day, incubated in $37^{\circ} \mathrm{C}$. $\mathrm{H}_{2} \mathrm{O}$ bath: No hemolysis in 16 hours. (c) As in (b) but with 'pamaquine $\mathrm{HCl}$ added to control plasma in concentrations of 100, 200,400,1,600,3,200 gammas per liter: No hemolysis in 16 hours. (d) RBC of control (0) receiving pamaquine plus BRO's plasma (0): No hemolysis after 16 hours at $37^{\circ} \mathrm{C}$. Thus, in vivo hemolysis of BRO's RBC not reproducible in vitro by these studies. 
TABLE VIII

Hemolytic reaction to pamaquine naphthoate (second course)

Patient: BRO. Negro, male

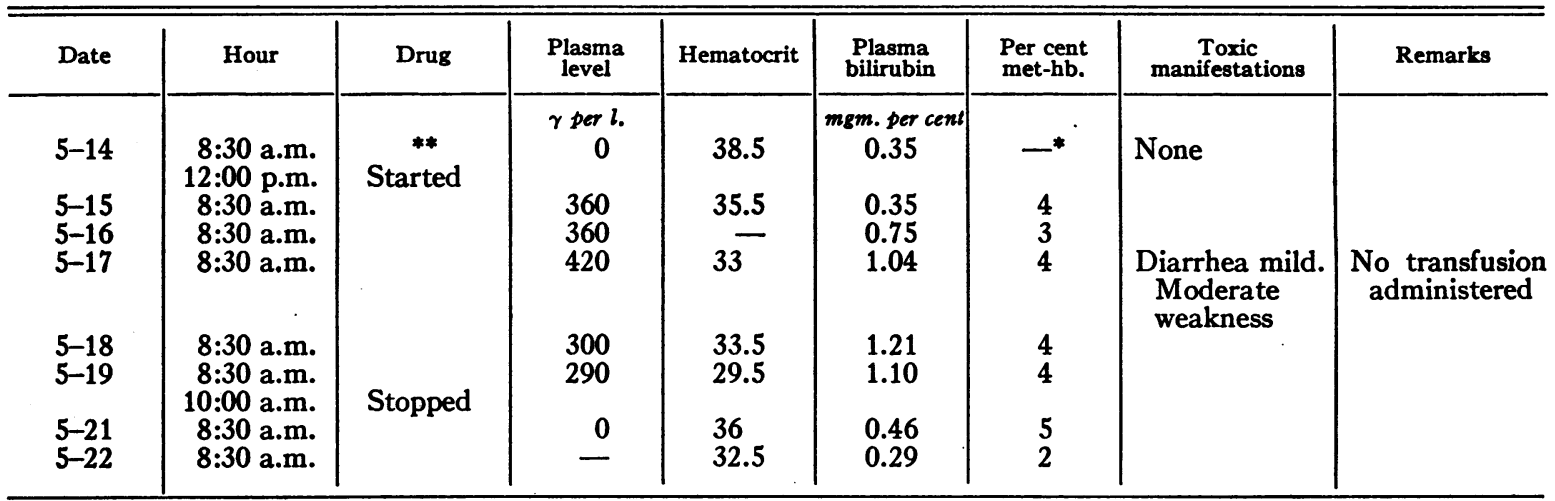

* Not done.

out any untoward reaction) were coded and forwarded to Dr. Philip Levine for analysis. The results of his studies appear in Table IX. It

TABLE IX

Analysis* of individual blood differences of six patients who received pamaquine naphthoate with and without hemolytic reactions

\begin{tabular}{|c|c|c|c|c|c|c|c|}
\hline $\begin{array}{l}\mathrm{Pa}- \\
\text { tient }\end{array}$ & $\begin{array}{c}\text { Toxic } \\
\text { reaction }\end{array}$ & Group & $\mathbf{M N}$ & $\begin{array}{l}\text { Anti- } \\
\text { Rho }\end{array}$ & Anti- & Anti- & Rh type \\
\hline $\begin{array}{l}\text { BRO } \\
\text { JOR } \\
\text { STA }\end{array}$ & $\begin{array}{l}\text { Hemolytic } \\
\text { Hemolytic } \\
\text { Abdominal } \\
\text { pain }\end{array}$ & $\begin{array}{l}\mathbf{A}\left(\mathbf{A}_{1}\right) \\
\mathbf{B} \\
0\end{array}$ & $\begin{array}{l}\text { M } \\
\text { MN } \\
M N\end{array}$ & $\begin{array}{l}+ \\
+ \\
0\end{array}$ & $\begin{array}{l}0 \\
+ \\
0\end{array}$ & $\begin{array}{l}+ \\
+\end{array}$ & $\begin{array}{l}\mathrm{Rh}_{2} \\
\mathrm{Rh}_{1} \\
\mathrm{Rh} \text { negative }\end{array}$ \\
\hline $\begin{array}{l}\text { BUT } \\
\text { PRO } \\
\text { ScH }\end{array}$ & $\begin{array}{l}\text { None } \\
\text { None } \\
\text { None }\end{array}$ & $\begin{array}{l}0 \\
0 \\
A\left(A_{2}\right)\end{array}$ & $\begin{array}{l}\text { M } \\
\text { MN } \\
\text { MN }\end{array}$ & $\begin{array}{l}+ \\
o \\
+\end{array}$ & $\begin{array}{l}0 \\
0 \\
+\end{array}$ & $\stackrel{+}{+}$ & $\begin{array}{l}\mathrm{Rh}_{2} \\
\mathrm{Rh} \text { negative } \\
\mathrm{Rh}_{1}\end{array}$ \\
\hline
\end{tabular}

* Performed by Dr. Philip Levine, Ortho Research Foundation, Linden, New Jersey.

will be noted that none of these grouping factors, single or in combination, appear to be related to hemolytic susceptibility to pamaquine.

Abdominal pain occurred in 4 patients. One of these (STA) had such a severe episode that the drug had to be withdrawn (Table $\mathrm{X}$ ). The pain was of a griping character, and was concentrated in the umbilical area. He also complained of moderate headache and nausea. The other 3 had short bouts of mild pain following some of the drug doses, but all were able to complete their schedules without mishap.

Of 26 patients (omitting the 2 hemolytic reactors), 11 had increases in serum bilirubin (7) of more than $0.5 \mathrm{mgm}$. per cent. These changes represent the differences between samples examined prior to, and at, the completion of treatment. Seven of these individuals were concentrated in the 11 patients who received $180 \mathrm{mgm}$. of pamaquine daily for 8 days.

Fourteen of 27 patients (omitting the 2 hemolytic reactors) had decreases in their hematocrit indices of the order of 3 or more. All 14 occurred among the 18 patients who received drug for 8 days.

The total leukocyte counts diminished by 1 thousand or more in 11 of 27 patients, remained unchanged in 9, and increased by 1 thousand or more in 7 others. Two of the 11 decreases finished with counts of 3 to 4 thousand per cubic millimeter.

Neither drug fever nor urinary abnormalities were encountered in any of the 36 patients.

\section{COMMENTS}

The data demonstrate quite clearly that when either 160 or $180 \mathrm{mgm}$. of pamaquine naphthoate are administered on the day before, the day of, and for 5 or 6 days (1-1-5 or 1-1-6) following sporozoite inoculation with $P$. vivax (McCoy), clinical expression of the disease may be delayed, or prevented, for months. Similar results may be anticipated with as few as 3 postinoculation days (1-1-3) treatment when $P$. falciparum (Costa) is the test parasite employed. 
TABLE $X$

Severe abdominal pain necessitating withdrawal of pamaquine naphthoate

Patient: STA. White, male. P. vivax (McCoy)

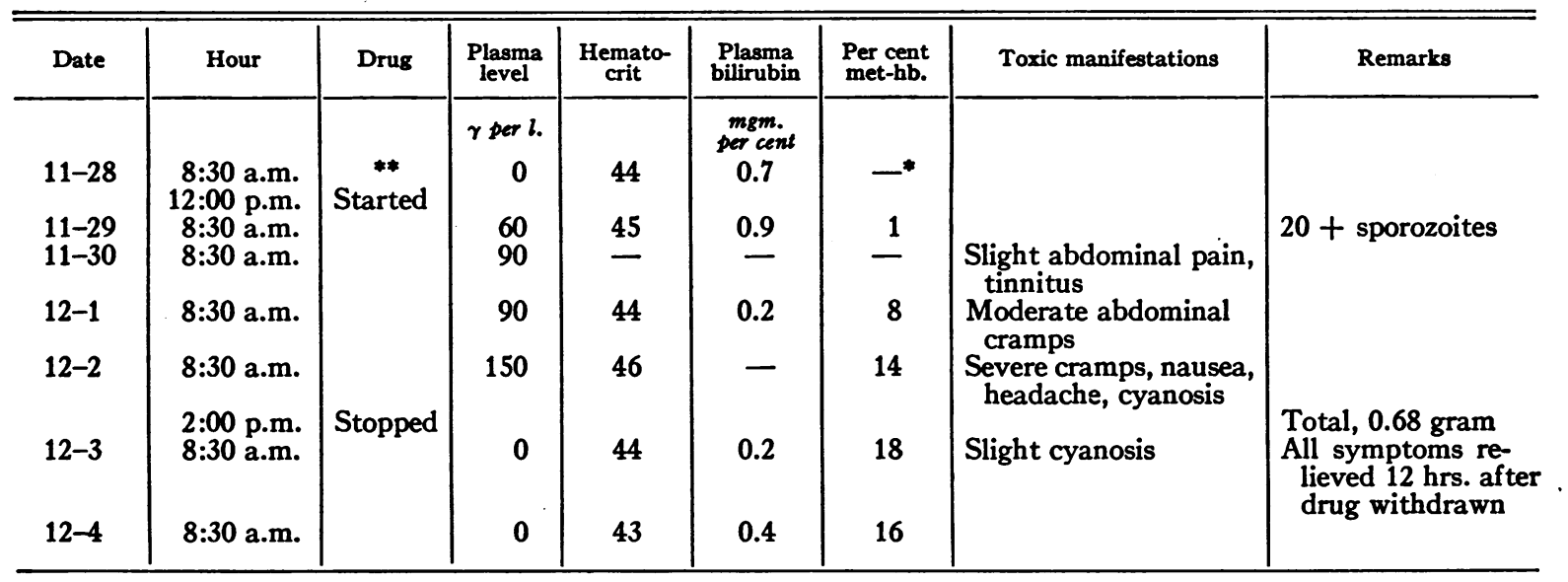

* Not done.

This is quite different from experiences with quinacrine (atabrine), for one achieves suppression ( $P$. vivax) or suppression-until-cure $(P$. falciparum) with this compound only if its administration is continued through the period of the expected primary attack. A further indication of the differences between the mode of action of pamaquine and atabrine or quinine is demonstrated by the effect of combining pamaquine with 1 of the other 2 for the treatment of vivax relapses. Such combined therapy will usually prevent further relapses. Dixon's study (8), while not the first of its kind, illustrates this point quite clearly.

Our study also highlights again the fact that falciparum and vivax parasites differ considerably in their susceptibility to antimalarial drugs. Whether this means that the 2 have such different life cycles that a drug must have a particular form to affect adversely one species and not the other, is pure conjecture.

Although our experiments failed to demonstrate as complete protection as was achieved by James in his trials with the Roumanian strains, nor, on the other hand, were the attained results as poor as those reported by Alving et al (9) with the markedly relapsing Chesson strain of South $\mathrm{Pa}$ cific vivax, they did accomplish their basic purpose, which was to determine whether James's results could be supported sufficiently to warrant
** 40 mgm. q. 6 hrs. $\times 12$, then 20 mgm. q. 4 hrs. $\times 7$.

an extensive chemical synthesis program to find other, less toxic, more active pamaquine analogs.

Alving et al employed doses of $90 \mathrm{mgm}$. of active pamaquine base per day on a 1-1-6 regime against the Chesson vivax strain in 5 subjects. Three of these patients developed malaria after 18,19 , and 106 days, whereas the remaining 2 have been observed for 402 negative days. These results, coupled with those of James and ourselves, illustrate again the danger of generalizing upon the subject of antimalarial therapy from experiences with a single strain of parasites.

\section{SUMMARY AND CONCLUSIONS}

1. Pamaquine naphthoate was administered to 36 paretics as a prophylactic against mosquitoinduced infections with $P$. vivax (McCoy) and $P$. falciparum (Costa).

2. Daily doses of either 160 or $180 \mathrm{mgm}$. administered the day before, the day of, and for 5 or 6 days following the day of inoculation with $P$. vivax ( $\mathrm{McCl}$ ) have prevented or postponed the primary attack for months. ${ }^{8}$ In the case of $P$. falciparum (Costa) postinoculation treatment could be shortened to 3 days with similar results,

8 Addendum: 15 January, 1947. The number of days of negative observation, through this date, for those patients still available for follow-up, were as follows:

$P$. vivax. POR, 690; LEW, 728; HAL, 648; BEA; 410.

P. falciparum. COO, 774; SMI, 340; BUT, 670; WEL, 465 ; RIN, 543; DAV, 345; PRO, 348; ScH, 474. 
except that delayed primary attacks were not observed.

3. Two instances of acute hemolytic anemia were encountered among 11 negro patients. One of these was re-exposed to the drug, and promptly had another hemolytic episode. This type of reaction was not related to the recipient's blood group.

4. Methemoglobinemia was regularly encountered in all subjects.

5. Elevations of the serum bilirubin and moderate hematocrit decreases were commonly noted among those receiving the higher, more prolonged courses, regardless of race.

6. Pamaquine naphthoate is rapidly absorbed and excreted.

7. The mode of action of pamaquine as a malaria prophylactic or suppressive is not explained, although such activity appears to be a function of the parasite species (and strain) employed, the total amount of drug ingested, and the number of days the drug is administered in relation to the inoculation day.

The authors are indebted to Dr. William B. Wendel for his supervision of the chemical analyses, to Dr. Yan Tim Wong for clinical aid, and to Miss Anna MacNicholas for technical assistance.

\section{BIBLIOGRAPHY}

1. James, S. P., Nicol, W. D., and Shute, P. G., On the prevention of malaria with plasmaquine. Lancet, 1931, 2, 341.

2. Quarterly Bulletin, Health Organization, League of Nations, 1933, 2, No. 2, June.

3. Brodie, B. B., Udenfriend, S., and Taggart, J. V., Analysis of basic organic compounds in biological tissues: 4. Coupling with diazonium salts. Fed. Proc., Part II, 1946, 5, 125.

4. Wendel, William B. To be reported.

5. Lyons, C., Penicillin therapy of surgical infections in the U. S. Army. J. A. M. A., 1943, 123, 16, 1007.

6. Hindle, J. A., Rose, A. S., Trevett, L. D., and Prout, C., The effect of penicillin on inoculation malaria. N. Eng. J. Med., 1945, 232, 5, 133.

7. Malloy, H. T., and Evelyn, K. A., The determination of bilirubin with the photoelectric colorimeter. J. Biol. Chem., 1937, 119, 481.

8. Dixon, H. B. F., A report on 600 cases of malaria treated with plasmoquine and quinine (Abst.). Trop. Dis. Bull., 1933, 30, 12, 846.

9. Alving, A. S., Eichelberger, L., Craige, B., Jr., Jones, R., Jr., Pullman, T. N., and Whorton, C. M., A study of the prophylactic effect of several 8amino quinolines including plasmochin for South Pacific (Chesson) vivax malaria. Presented at the 38th Annual Meeting of the American Society for Clinical Investigation, Atlantic City, New Jersey, 27 May 1946. Abstracted in J. Clin. Invest., 1946, 25, 910. 